[Agr. Biol. Chem., Vol. 36, No. 9, p. 1473 1480, 1972]

\title{
Purification and Properties of Acid Carboxypeptidase II from Aspergillus oryzae
}

\author{
By Tadanobu NakadaI, Seiichi Nasuno and Nobuyoshi IguchI \\ Noda Institute for Scientific Research, \\ Noda-shi, Chiba-ken \\ Received December 22, 1971
}

\begin{abstract}
Acid carboxypeptidase II from Aspergillus oryzae was purified from the rivanol nonprecipitated fraction. The purified enzyme was homogeneous on polyacrylamide gel disc electrophoresis. The optimum activity of the enzyme lay at $\mathrm{pH} 3.0$ for carbobenzoxy-Lglutamyl-L-tyrosine. The enzyme was inhibited by diisopropylphosphorofluoridate and $\mathrm{SH}$ reagents such as $p$-chloromercuribenzoate and monoiodoacetate, but not by such metal chelating agents as ethylenediaminetetraacetate, $\alpha, \alpha^{\prime}$-dipyridyl and $o$-phenanthroline. The molecular weight of the enzyme was estimated to be about 105,000 .
\end{abstract}

In previous papers ${ }^{1,2)}$ peptidases from Aspergillus oryzae or Asp. sojae were found to play an important role in digestion of the peptides to yeild free amino acids. The acid carboxypeptidase I from Asp. oryzae was purified from the rivanol non-precipitated fraction and its properties were described in a previous paper. ${ }^{3}$ ' This paper deals with the purification and some properties of acid carboxypeptidase II as a part of the systematic studies on peptidases from Asp. oryzae.

\section{MATERIALS AND METHODS}

To $1 \mathrm{ml}$ of $5 \times 10^{-4} \mathrm{M}$ solution of Cbz-Glu-Tyr (Protein Research Foundation, Osaka, Japan) in $0.05 \mathrm{M}$ acetate buffer (pH 3.0) was added $50 \mu 1$ of enzyme solution. After incubation at $30^{\circ} \mathrm{C}$ for $20 \mathrm{~min}$, reaction was stopped by the addition of $0.5 \mathrm{ml}$ of ninhydrin solution. Then acid carboxypeptidase II activity was determined by the same method as re-

\footnotetext{
Abbreviations used in this paper: $\mathrm{Cbz}$, carbobenzoxy; Aoc, t-amyloxycarbonyl; Bz, benzoxy; PyroGlu, pyroglutamic acid; $\beta$-NA, $\beta$-naphthylamide; amino acids, first three letters abbreviation; Gln, glutamine; Asn, asparagine; approx., approximately; mol. wt., molecular weight; CPase, carboxypeptidase; DFP, diisopropylphosphorofluoridate; EDTA, ethylenediaminetetraacetate.
}

ported in the previous papers. ${ }^{3, t)}$ A unit of enzyme activity was defined as the enzyme quantity which liberates $1 \mu$ mole of amino acid (as glutamic acid) from the substrate (Cbz-Glu-Tyr) per min under these conditions. All the other experimental methods were described in detail in the previous paper. ${ }^{3}$,

\section{RESULTS}

\section{Column chromatography on DEAE-Sephadex A-50}

The fractions of acid carboxypeptidase II from DEAE-cellulose chromatography reported previously ${ }^{3}$ were adjusted to $\mathrm{pH} 6.0$ and charged on a column $(3 \div 30 \mathrm{~cm})$ of DEAESephadex A-50 (Pharmacia, Uppsala, Sweden) equilibrated with $0.01 \mathrm{~m}$ phosphate buffer at pH 6.0. After the column had been washed with the same buffer, elution of the adsorbed protein was performed by a linear gradient of $\mathrm{NaCl}$ concentration. The reservoir was filled with 2 liters of $0.4 \mathrm{M} \mathrm{NaCl}$ in $0.01 \mathrm{~m}$ acetate buffer ( $\mathrm{pH}$ 5.5) and the mixing chamber contained 2 liters of the same buffer. Figure 1 illustrates the elution pattern of acid CPase II. Fractions 198 to 248 were pooled, adjusted to $\mathrm{pH} 5.5$ and desalted by dialysis against distilled water. 


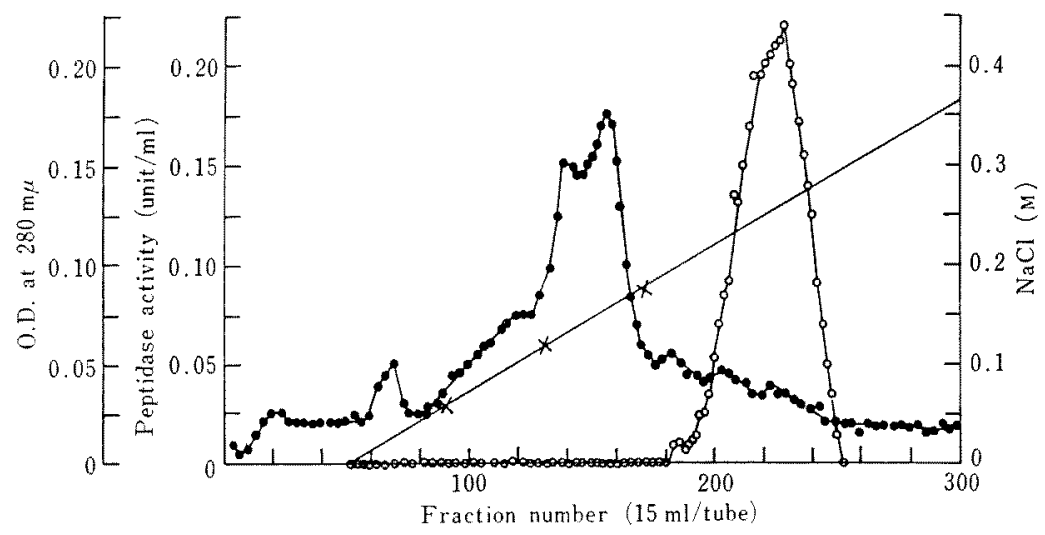

FIG. 1. Chromatography of Acid CPase II on DEAE-Sephadex A-50.

See the text for experimental details. $O-O$ : peptidase activity.

$\mathrm{NaCl}$ concentration. $730 \mathrm{ml}$ of acid CPase II solution containing $143 \mathrm{mg}$ of activity 1.18 units/mg protein) was used.

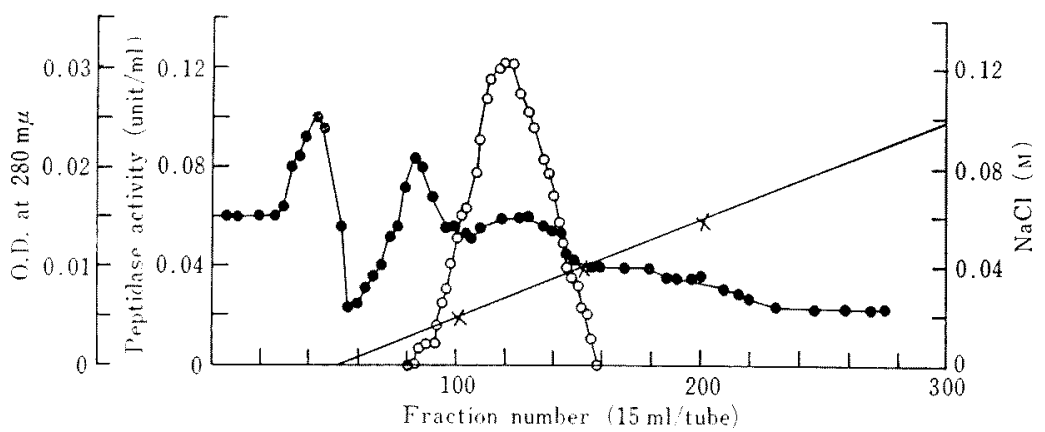

FIG. 2. Chromatography of Acid CPase II on SE-cellulose.

See the text for experimental details. $O-O$ : peptidase activity, -0 : O.D. at $280 \mathrm{~m} \mu$. $x-x$ : $\mathrm{NaCl}$ concentration. $700 \mathrm{ml}$ of acid CPase II solution containing $31 \mathrm{mg}$ of protein (specific activity 2.78 units/mg protein) was used.

\section{Column chromatography on SE-cellulose}

The dialyzed solution of acid CPase II from DEAE-Sephadex $\mathrm{A}-50$ was adjusted to $\mathrm{pH}$ 3.5 and put onto the column $(3 \times 13 \mathrm{~cm})$ of SE-cellulose (Serva) equilibrated with $0.01 \mathrm{M}$ acetate buffer $(\mathrm{pH} 3.5)$. Linear gradient elution was performed by introducing $0.1 \mathrm{M}$ $\mathrm{NaCl}$ in $0.01 \mathrm{M}$ acetate buffer ( $\mathrm{pH} \mathrm{4.5)} \mathrm{through}$ a 2-liter mixing chamber containing the same buffer. The flow rate was adjusted to $100 \mathrm{ml} /$ $\mathrm{hr}$ and $15-\mathrm{ml}$ fractions were collected. A typical elution pattern of acid CPase II is shown in Fig. 2. Fractions 94 to 150 were pooled and immediately adjusted to $\mathrm{pH} 5.5$.

\section{Gel filtration on Sephadex G-200}

The above enzyme preparation obtained from SE-cellulose chromatography was concentrated to $3 \mathrm{ml}$ by a Diaflo UM-1 (type; 401, Amicon Co.) and applied to a column $(2.8 \times 118 \mathrm{~cm})$ of Sephadex G-200 equilibrated with $0.1 \mathrm{M}$ acetate buffer at $\mathrm{pH} 5.5$ Elution was performed with the same buffer and $15-\mathrm{ml}$ fractions were collected. Figure 3 shows a 
Table I. Purification of Acid Carboxypeptidase II.

\begin{tabular}{lcccc}
\hline \multicolumn{1}{c}{ Procedure } & $\begin{array}{c}\text { Total } \\
\text { volume } \\
\mathrm{ml}\end{array}$ & $\begin{array}{c}\text { Total } \\
\text { activity } \\
\text { Units }\end{array}$ & $\begin{array}{c}\text { Specific } \\
\text { activity } \\
\text { U/mg protein }\end{array}$ & $\begin{array}{c}\text { Yield } \\
\%\end{array}$ \\
\hline Crude enzyme solution & 10,100 & 5030 & 0.0695 & 100 \\
Batchwise treatment with Amberlite IRC-50 & 10,200 & 2200 & 0.128 & 96.5 \\
Fractionation with ammonium sulfate & 235 & 1210 & 0.202 & 53.0 \\
Rivanol precipitation & 235 & 552 & 0.269 & 24.2 \\
DEAE-cellulose chromatography & 730 & 169 & 1.18 & 7.40 \\
DEAE-Spehadex A-50 chromatography & 700 & 142 & 2.78 & 6.23 \\
SE-cellulose chromatography & 740 & 121 & 4.55 & 5.30 \\
Gel filtration on Sephadex G-200 & 146 & 38.7 & 9.55 & 1.70 \\
\hline
\end{tabular}

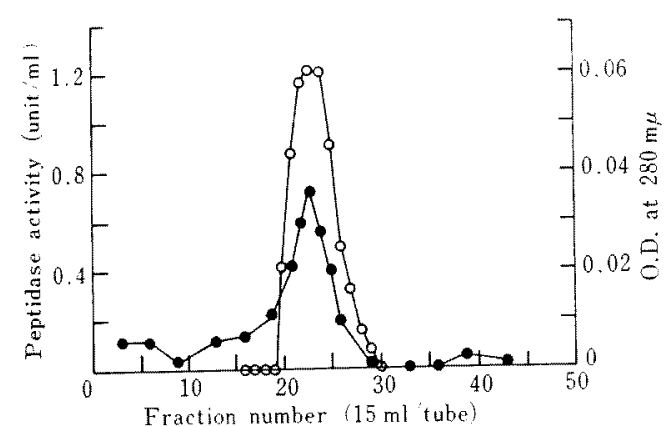

FIG. 3. Gel Filtration of Acid CPase II through Sephadex G-200.

See the text for experimental details.

O-O: peptidase activity. -O: O.D. at $280 \mathrm{~m} \mu$.

typical elution pattern of acid CPase II. Pooled fractions of 20 to 29 were frozen and stored at $-15^{\circ} \mathrm{C}$. A summary of the purification procedure is shown in Table I.

Determination of molecular weight by gel flitration

Figure 4 is plots of elution volume $(\mathrm{Ve})$ against logarithms of molecular weights of standard proteins and acid CPase II obtained through a Sephadex G-200 (pH 5.5) column. The molecular weight of acid CPase II determined by gel filtration method was calculated to be 105,000 .

\section{Disc electrophoresis}

To check the purity of the enzyme, the final

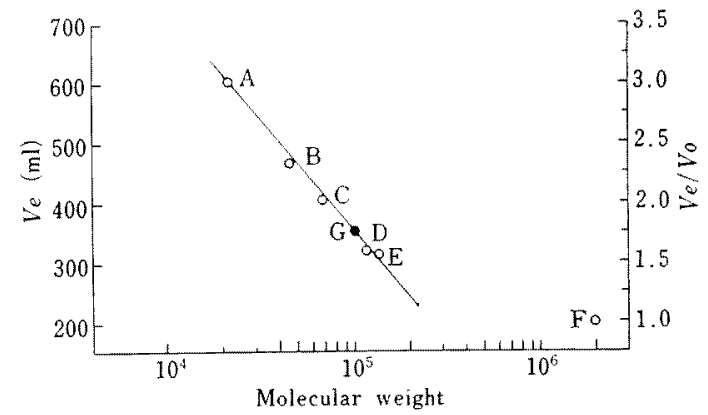

FIG. 4. Plots of Elution Volume, Ve, against Logarithms of Molecular Weights for Proteins on a Sephadex G-200 Column.

Column $(2.8 \times 118 \mathrm{~cm})$ was equilibrated with $0.1 \mathrm{M}$ acetate buffer at $\mathrm{pH} 5.5 . \quad 0.1 \mathrm{M}$ acetate buffer (pH 5.5) was applied for the elution of proteins.

A: trypsin. B: ovalbumin. C: human albumin. $\mathrm{D}$ : intestinal alkaline phosphatase, $\mathrm{E}$ : human albumin dimer. F: blue dextran. G: acid CPase II.

enzyme preparation was submitted to polyacrylamide gel disc electrophoresis at $\mathrm{pH} 9.4$ as reported in the previous paper. ${ }^{3)}$ A single protein band corresponding to acid CPase II was found as shown in Fig. 5.

\section{Action on various peptides}

The hydrolytic action of the acid CPase II on various peptides was examined by the ninhydrin method. To $0.5 \mathrm{ml}$ of purified enzyme solution in $0.1 \mathrm{M}$ acetate buffer at pH $3.0(27.8 \mu \mathrm{g}$ protein $/ \mathrm{ml}$, specific activity; 9.55 units $/ \mathrm{mg}$ protein) was added $0.5 \mathrm{ml}$ of 


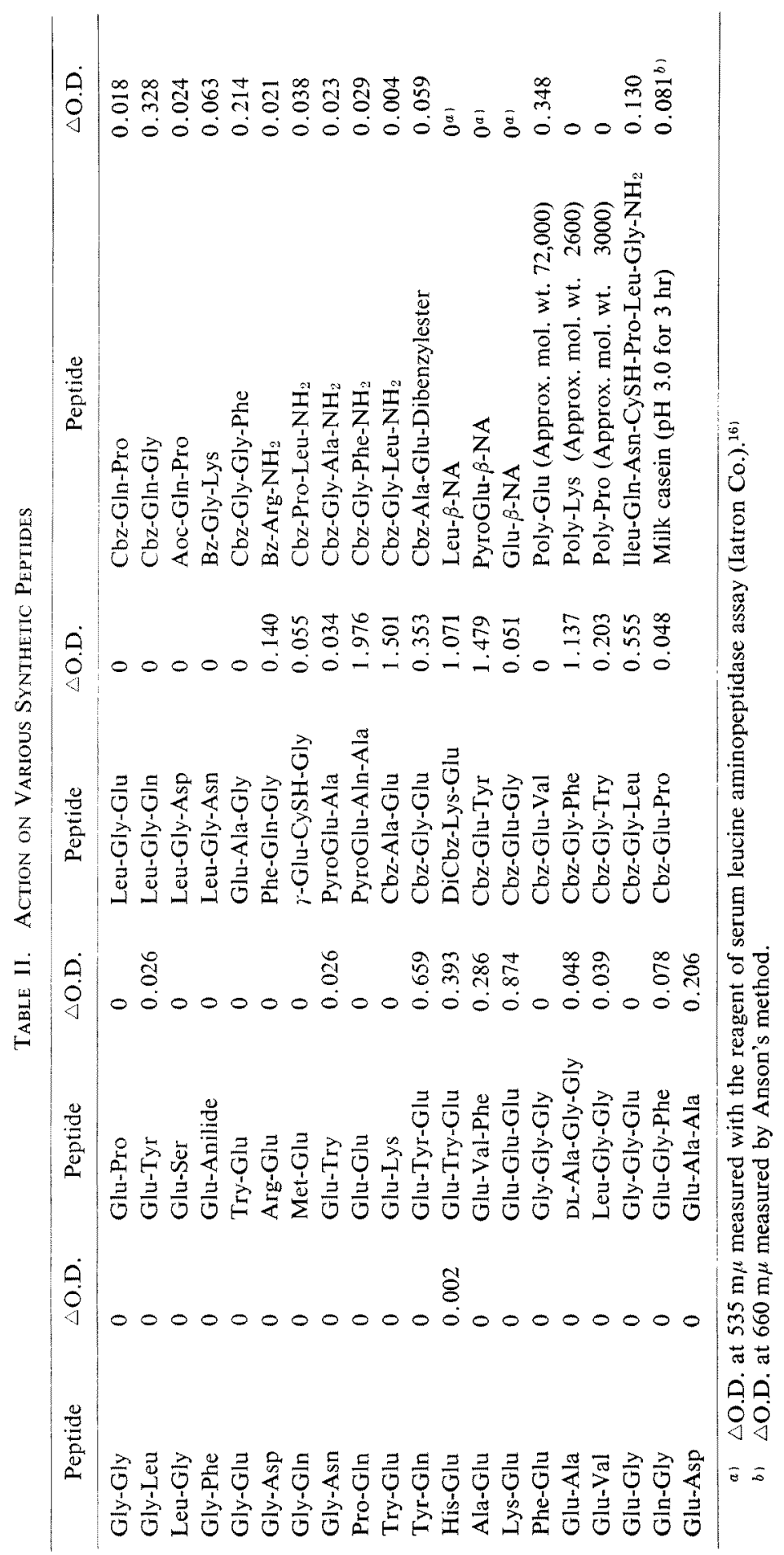


each $5 \times 10^{-4}$ M solution for di- and tri-peptides and $10^{-3} \mathrm{M}$ solution for other peptides. After incubation at $30^{\circ} \mathrm{C}$ for $30 \mathrm{~min}$, reaction was stopped by the addition of $0.5 \mathrm{ml}$ of ninhydrin reagents, followed by heating at $100^{\circ} \mathrm{C}$ for $15 \mathrm{~min}$ and the optical density at $570 \mathrm{~m} \mu$ was measured by the same method as reported in the previous paper. ${ }^{3)}$ The results are summarized in Table II. Acid CPase II hydrolyzed the peptides that possess masked or bulky $\mathrm{N}$-terminal. Two-tenth $\mathrm{ml}$ of enzyme solution $(27.8 \mu \mathrm{g}$ protein $/ \mathrm{ml})$ in $0.1 \mathrm{M}$ acetate buffer (pH 3.0) was added to $1 \mathrm{mg}$ of $\alpha$-Glu-Val-Phe (Cyclo Chemical Corp.). After incubation for 5 and $24 \mathrm{hr}$ at $30^{\circ} \mathrm{C}, 10-\mu \mathrm{l}$ aliquots of the reaction mixture were spotted on a thin-layer of Kieselgel G (E. Merck AG. Darmstadt) and developed at $25^{\circ} \mathrm{C}$ for $3 \mathrm{hr}$ by the ascending method using a mixture of $n$-butanol, acetic acid and water $(4: 1: 1)$ as the solvent. The thin-layer was then dried and detection of separated components was carried out by spraying of $0.25 \%$ solution of ninhydrin dissolved in ethanol. Based on the results shown in Fig. 6, the enzyme hydrolyzed the tripeptide from $\mathrm{C}$-terminal and was considered to be CPase.

Time courses of hydrolysis of two peptides

Time courses of acid CPase II action on two peptides are shown in Fig. 7. Activity ratio for Cbz-Glu-Tyr (pH 3.0) and Cbz-Ala-Glu (pH 4.0) was 4.18: 1.

\section{Effect of $p H$ on acid CPase II}

The effect of $\mathrm{pH}$ on acid CPase II activity was studied with some peptides. Purified acid CPase II was found to be most active at pH 3.0 for Cbz-Glu-Tyr (Fig. 8). The enzyme was stable in the $\mathrm{pH}$ range of 5 to 6 (Fig. 9).

\section{Effect of temperature on acid CPase II}

The activity of purified acid CPase II at various temperatures was determined with

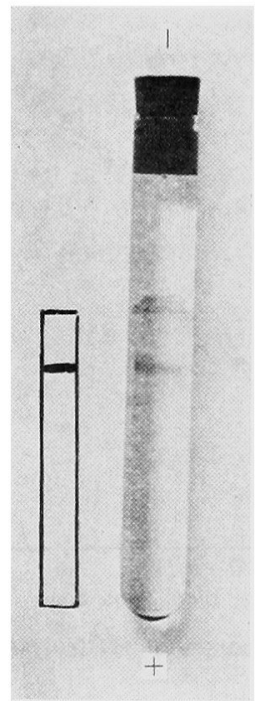

FIG. 5. Polyacrylamide Gel Electrophoresis of Purified Acid Carboxypeptidase II from Aspergillus oryzae at $\mathrm{pH} 9.4$ for $45 \mathrm{~min}$.

The operation was done in a cold room $\left(4^{\circ} \mathrm{C}\right)$ for $45 \mathrm{~min}$ at $4 \mathrm{~mA}$ per gel column according to the method of Davis ${ }^{17}$ for $\mathrm{pH} 9.4$ gel.

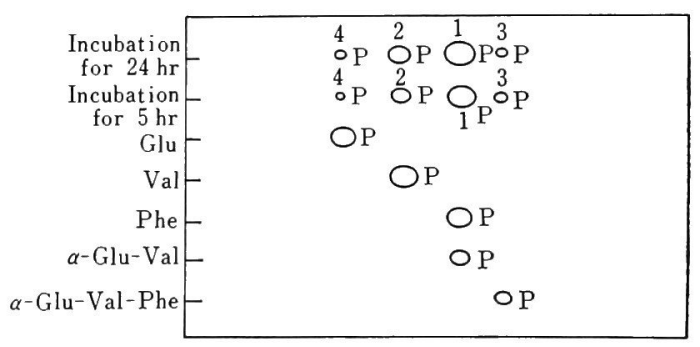

FIG. 6. Thin-layer Chromatogram of Products from $\alpha$-Glu-Val-Phe Hydrolyzed by Acid CPase II and Authentic Peptides and Amino Acids.

p: purple, spot 1: Phe and $\alpha$-Glu-Val, spot 2: Val, spot 3: $\alpha$-Glu-Val-Phe, spot 4: Glu.

See the text for experimental details.

Cbz-Glu-Tyr on 10-min incubation. The enzyme was found to be most active at $50^{\circ} \mathrm{C}$ as shown in Fig. 10. Heat stability test showed that the enzyme lost a half of the initial activity at $60^{\circ} \mathrm{C}$ after $10 \mathrm{~min}$ and lost its activity almost completely at $70^{\circ} \mathrm{C}$ on 10 -min incubation (Fig. 11). Calcium ions showed no 


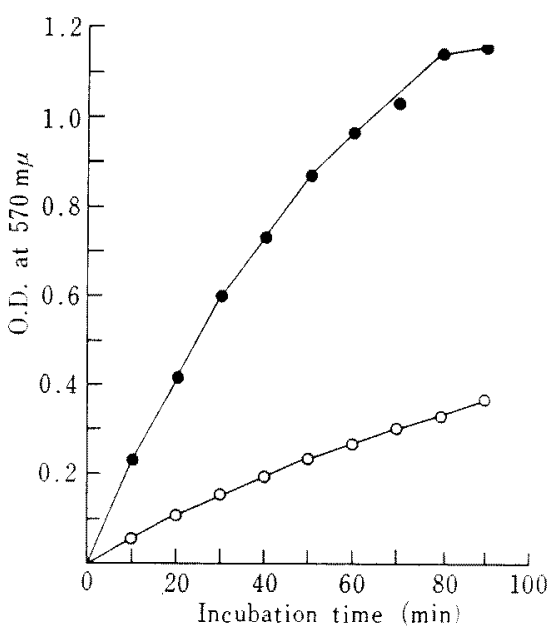

FIG. 7. Time Courses of Hydrolysis of Peptides by Acid CPase II.

The reaction mixture consisted of $100 \mu 1$ of the purified enzyme $(69.5 \mu \mathrm{g})$ and $10 \mathrm{ml}$ of Cbz-GluTyr in $0.05 \mathrm{M}$ acetate buffer at pH 3.0 (-) or Cbz-Ala-Glu in $0.05 \mathrm{M}$ acetate buffer at $\mathrm{pH} 4.0$ (O-O). Hydrolysis at $30^{\circ} \mathrm{C}$ was determined with $1 \mathrm{ml}$ aliquots taken at various time.

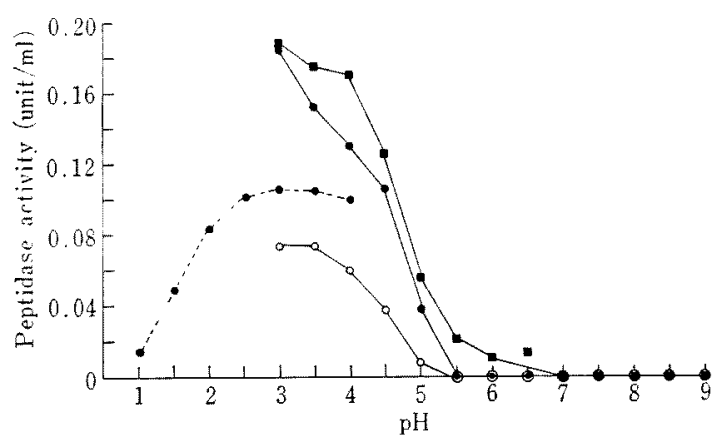

Fig. 8. Effect of $\mathrm{pH}$ on Acid CPase II.

The reaction mixtures containing $0.2 \mathrm{ml}$ of the purified enzyme, $0.3 \mathrm{ml}$ of the buffer and $0.5 \mathrm{ml}$ of the substrate were incubated for $10 \mathrm{~min}$ at $30^{\circ} \mathrm{C}$. Buffers used were $0.05 \mathrm{M}$ acetate buffer $(\mathrm{pH} 3.0$ to $6.0), 0.25 \mathrm{M}$ Trism $\mathrm{HCl}$ buffer $(\mathrm{pH} 6.5$ to 9.0$)$ and $0.5 \mathrm{M} \mathrm{CH}_{3} \mathrm{COONa}-\mathrm{HCl}$ buffer ( $\mathrm{pH} 1.0$ to 4.0 ). Substrate used; - Cbz-Glu-Tyr. O-O: CbzAla-Glu. घ-E: $\alpha$-Glu-Tyr-Glu (unit $/ \mathrm{ml} \times 10^{-1}$ ), -.-.- Cbz-Glu-Tyr (Enzyme with less activity was used in this experiment.)

protection of the enzyme against heat denaturation.

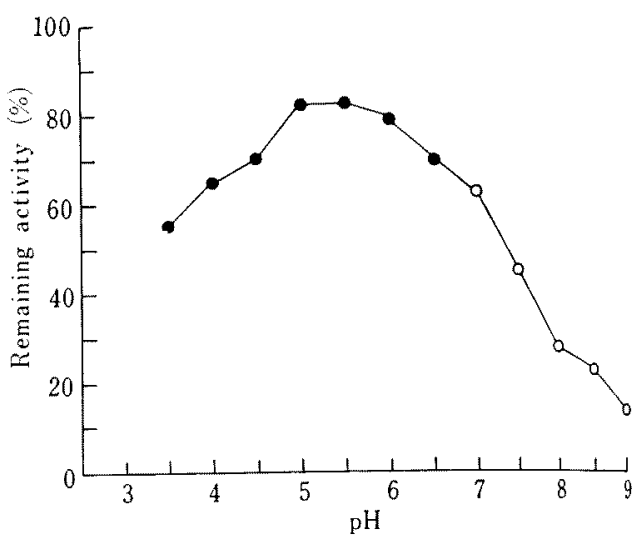

FIG. 9. pH Stability of Acid CPase I.

To $25 \mu 1$ of $0.25 \mathrm{M}$ buffer of various $\mathrm{pH}$ values, $100 \mu 1$ of purified and dialyzed enzyme solution (protein; $2.78 \mu \mathrm{g}$ ) was added and the mixture was incubated at $37^{\circ} \mathrm{C}$ for $2 \mathrm{hr}$. The activities remaining after the treatments are expressed as percentages of the initial activity. Buffers used were; -0 : acetate buffer $(\mathrm{pH} 3.5$ to 6.0$), 0-0$ : tris- $\mathrm{HCl}$ buffer (pH 6.5 to 9.0 ).

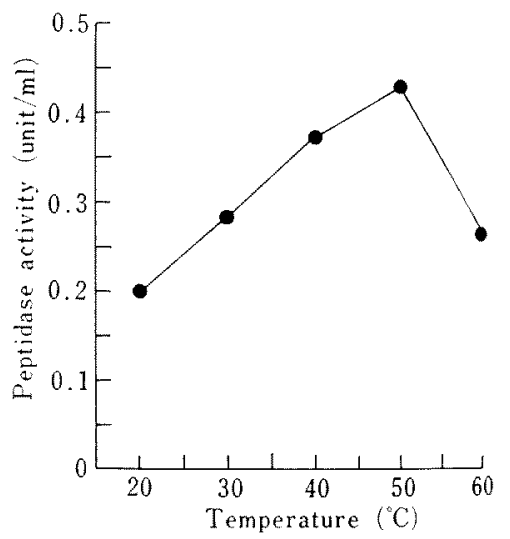

FIG. 10. Effect of Temperature on Activity of Acid CPase II.

The incubation mixtures contained $100 \mu \mathrm{l}$ of the purified enzyme solution $(2.78 \mu \mathrm{g})$ and $1 \mathrm{ml}$ of $5 \times 10^{-4} \mathrm{M}$ Cbz-Glu-Tyr in $0.05 \mathrm{M}$ acetate buffer (pH 3.0). Hydrolysis was assayed after 10 min at various temperatures.

\section{Effect of metal ion on the enzyme activity}

As shown in Table III, $\mathrm{Co}^{2+}, \mathrm{Mn}^{2+}, \mathrm{Ni}^{2+}$, $\mathrm{Pb}^{2+}, \mathrm{Cu}^{2+}$ and $\mathrm{Fe}^{2+}$ ions inhibited the enzyme to some extent at $10^{-3} \mathrm{M}$. Remarkable in- 


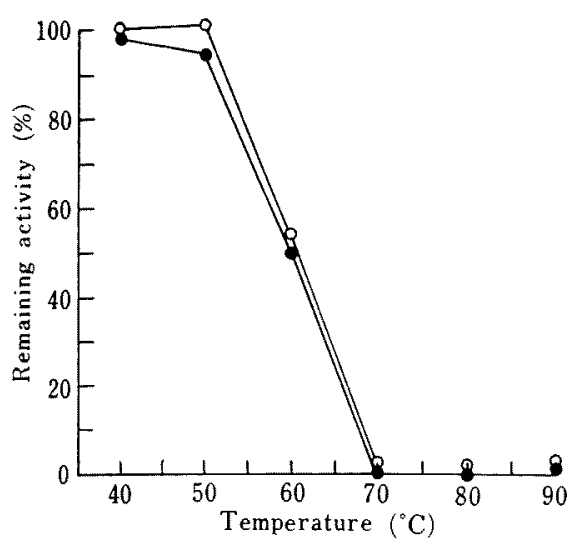

FIG. 11. Heat Stability of Acid CPase II.

The incubation mixtures consisting of $2.78 \mu \mathrm{g}$ of the purified enzyme and $100 \mu \mathrm{l}$ of $0.05 \mathrm{M}$ acetate buffer at $\mathrm{pH} 5.0$ with or without $10^{-2} \mathrm{M}$ of $\mathrm{Ca}\left(\mathrm{CH}_{3} \mathrm{COO}\right)_{2}$, were incubated at various temperatures for $10 \mathrm{~min}$. The activities remaining after the preincubation are expressed as percentages of the initial activity. - : without $\mathrm{Ca}\left(\mathrm{CH}_{3} \mathrm{COO}\right)_{2}$. $\mathrm{O}-\mathrm{O}: \mathrm{Ca}\left(\mathrm{CH}_{3} \mathrm{COO}\right)_{2}$ added.

Table III. Effect of Various Metal Salts on ACID CARboxypeptidase II

The assay system contained $0.2 \mathrm{ml}$ of metal salt (pH 5.5$), 0.3 \mathrm{ml}$ of dialyzed enzyme $(2.78 \mu \mathrm{g})$ and $0.5 \mathrm{ml}$ of $10^{-3} \mathrm{M} \mathrm{Cbz-Glu-Tyr}$ in $0.1 \mathrm{M}$ acetate buffer (pH 3.0). Hydrolysis was assayed after $10 \mathrm{~min}$ at $30^{\circ} \mathrm{C}$ with preincubation for $10 \mathrm{~min}$ at $30^{\circ} \mathrm{C}$. Enzyme activities were assayed by ninhydrin method and are expressed as percentages of the activity in the absence of metal salts.

\begin{tabular}{lcc}
\hline $\begin{array}{c}\text { Metal salts } \\
\text { added }\end{array}$ & $\begin{array}{c}\text { Concentration } \\
(\mathrm{M})\end{array}$ & $\begin{array}{c}\text { Relative activity } \\
(\%)\end{array}$ \\
\hline None & & 100 \\
$\mathrm{CoSO}_{4}$ & $10^{-3}$ & 67.0 \\
$\mathrm{MnCl}_{2}$ & $10^{-3}$ & 67.0 \\
$\mathrm{NiSO}_{4}$ & $10^{-3}$ & 79.3 \\
$\mathrm{ZnSO}_{4}$ & $10^{-3}$ & 87.1 \\
$\mathrm{MgSO}_{4}$ & $10^{-3}$ & 89.8 \\
$\mathrm{CaCl}_{2}$ & $10^{-3}$ & 93.5 \\
$\mathrm{FeSO}_{4}$ & $10^{-3}$ & 79.4 \\
${\mathrm{~Pb}\left(\mathrm{CH}_{3} \mathrm{COO}\right)_{2}}_{\mathrm{CuSO}_{4}}^{10^{-3}}$ & 77.7 \\
$\mathrm{HgCl}_{2}$ & $10^{-3}$ & 68.7 \\
\hline
\end{tabular}

hibition of the enzyme was observed by incubation with $4 \times 10^{-3} \mathrm{M} \mathrm{Hg}^{2+}$ ions.
Table IV. Effect of Various Reagents ON THE ACID CARBOXYPEPTIDASE II

The assay system contained $0.2 \mathrm{ml}$ of substances listed below ( $\mathrm{pH} 5.5), 0.3 \mathrm{ml}$ of dialyzed enzyme $(2.78 \mu \mathrm{g})$ and $0.5 \mathrm{ml}$ of $10^{-3} \mathrm{M} \mathrm{Cbz-Glu-Tyr}$ in $0.1 \mathrm{M}$ acetate buffer ( $\mathrm{pH} 3.0$ ). Hydrolysis was assayed after $10 \mathrm{~min}$ at $30^{\circ} \mathrm{C}$ with preincubation for $20 \mathrm{~min}$ at $30^{\circ} \mathrm{C}$.

\begin{tabular}{|c|c|c|}
\hline Inhibitor & $\begin{array}{c}\text { Concentra- } \\
\text { tion } \\
\mathrm{M}\end{array}$ & $\begin{array}{c}\text { Remaining } \\
\text { activity } \\
\%\end{array}$ \\
\hline None & & 100 \\
\hline EDTA & $5 \times 10^{-2}$ & 85.6 \\
\hline EDTA & $10^{-2}$ & 95.4 \\
\hline EDTA & $5 \times 10^{-3}$ & 94.6 \\
\hline EDTA & $4 \because 10^{-13}$ & 90.4 \\
\hline EDTA & $10^{-3}$ & 97.4 \\
\hline EDTA (Dialysis for $12 \mathrm{hr}$ ) & $10^{-3}$ & 102.0 \\
\hline$\alpha, \alpha^{\prime}$-Dipyridyl & $4 \times 10^{-3}$ & 114.3 \\
\hline o-Phenanthroline & $4 \because 10^{-3}$ & 119.0 \\
\hline$p$-Chloromercuribenzoate & $10^{-3}$ & 13.8 \\
\hline Monoiodoacetate & $4 \times 10^{-3}$ & 45.0 \\
\hline Sodium lauryl sulfate & $10^{-3}$ & 10.2 \\
\hline Potato inhibitor & $0.025 \%$ & 82.0 \\
\hline Sodium hexametaphosphate & $4 \times 10^{-3}$ & 88.6 \\
\hline Thiourea & $10^{-3}$ & 81.2 \\
\hline$\beta$-Mercaptoethanol & $4 \times 10^{-3}$ & 89.5 \\
\hline Sodium thioglycolate & $4 \times 10^{-3}$ & 68.5 \\
\hline DFP & $10^{-2}$ & 10.4 \\
\hline
\end{tabular}

Effect of various reagents on the enzyme activity

Table IV shows the results of experiments undertaken in an attempt to find out some informations about the active site of acid CPase II. Metal chelating agents such as EDTA, $\alpha, \alpha^{\prime}$-dipyridyl and $o$-phenanthroline did not show any inhibitory effect on the peptidase activity. The enzyme activity was inhibited by DFP, sodium lauryl sulfate and by specific sulfhydryl reagents like $p$-chloromercuribenzoate and monoiodoacetate.

\section{DISCUSSION}

The molecular weight of Asp. oryzae acid CPase II was determined to be about 105,000 by gel filtration method. It is noteworthy that this value is larger than the molecular weights of all other known CPase except for 
the acid CPase from Asp. saitoi (trimer; $\left.155,000^{5}\right)$ and the acid CPase I from Asp. oryzae $\left(120,000^{3}\right)$. For example, the molecular weights of bovine CPase $A \alpha^{6}$. spiny pacific dogfish CPase $A,{ }^{7)}$ CPase $B,{ }^{8}$ fungal CPase of Phymatotrichum omnivorum ${ }^{9}$ and Asp. saitoi ${ }^{5)}$ (monomer) and barley CPase ${ }^{10)}$ were 34,600 , $35,000,51,000$ and 90,000 respectively.

Since the optimum $\mathrm{pH}$ for Cbz-Glu-Tyr lies at $\mathrm{pH} 3.0$, the CPase II from Asp. oryzae was named acid CPase. This value is much lower compared with the optimum $\mathrm{pH}$ of CPases from other sources except that of Asp. saitoi. ${ }^{11}$ The optimum pHs are 5.2 with Cbz-Gly-Ala for barley CPase, ${ }^{10)} 7.0$ with Cbz-Gly-Phe for Phymatorichum ommivorum CPase, ${ }^{9)} 5.3$ with $\mathrm{Cbz}$-Leu-Phe for citrus fruit CPase $C,{ }^{12)} 6.0$ to 6.2 for brewer's yeast peptidase $\alpha, \beta^{13)}$ and 3.1 with Cbz-Glu-Tyr for Asp. saitoi acid CPase. ${ }^{11}$

The acid CPase II from Asp. oryzae was inhibited by $\mathrm{SH}$ reagents, like yeast peptidase $\alpha, j^{13)}$ and barley CPase, ${ }^{10 j}$ but not inhibited by metal chelating agents, like barley CPase, ${ }^{10)}$ yeast peptidase $\beta,{ }^{13)}$ CPase $C^{12}$ and the acid CPase from Asp. saitoi. ${ }^{5}$ Also, acid CPase II from Asp. oryzae was inhibited by DFP, like yeast peptidase $\beta,{ }^{13}$ ) CPase $C^{12}$ and the acid CPase from Asp. saitoi. ${ }^{5}$

Acid CPase II degraded poly- $\alpha, \mathrm{L}-$ glutamic acid as CPase $\mathrm{B}^{14 t}$ yeast proteinase $\mathrm{B}^{15)}$ and acid CPase $\mathrm{I}^{31}$ and also degraded the peptides that possess bulky $\mathrm{N}$-terminus as acid CPase $\mathrm{I}^{3}$

Acknowledgements. The authors wish to thank
Profs. T. Asai, K. Arima and Y. Ikeda for their kind guidance. The authors are grateful to Miss M. Yama. zaki for her technical assistance. We also wish to thank Dr. S. Sakakibara for his kind supply of peptides.

\section{REFERENCES}

1) T. Nakadai, S. Nasuno and N. Iguchi, Agr. Biol. Chem., 36, 261 (1972).

2) T. Nakadai, S. Nasuno and N. Iguchi, ibid, 36, 1239 (1972).

3) T. Nakadai, S. Nasuno and N. Iguchi, ibid., 36, 1343 (1972).

4) T. Nakadai, S. Nasuno and N. Iguchi, Chomi Kagaku (Seasoning Science), 18, 435 (1971).

5) E. Ichishima, Abstracts of Papers, Annual Meeting of Japanese Biochemical Society, Sendai, Japan, August, 43, 728 (1971).

6) J. P. Bargetzi, K. S. U. Sampath Kumar, D.J. Cox, K. A. Walsh and H. Neurath, Biochemistry, 2, 1468 (1963).

7) A. G. Locko and H. Neurath, ibid., 9, 4680 (1970),

8) J. E. Folk, K. A. Peiz, W. R. Carrol and J.A. Gladner, J. Biol. Chem., 235, 2272 (1960).

9) J. D. Boston and J. M. Prescott, Arch. Biochem. Biophys., 128, 88 (1968).

10) K. Visuri, J. Mikola and T. M. Enari, European J. Biochem., 7, 193 (1969).

11) E. Ichishima, Biochim. Biophys. Acta, 258, 274 (1972).

12) H. Zuber, Nature, 201, 613 (1964).

13) F. Felix and N. Brouillet, Biochim. Biophys. Acta, 122, 127 (1966).

14) W. G. Miller, J. Am. Chem. Soc., 86, 3913 (1964).

15) R. Hayashi, T. Higasa and T. Hata. Abstracts of Papers, Annual Meeting of Agricultural Chemical Society, Tokyo, Japan, April, 1971, p. 203.

16) J. A. Goldbarg and A. M. Rutenburg, Cancer, 11, 283 (1958).

17) B. J. Davis, Ann. N. Y. Acad. Sci., 121, 404 (1964). 